Gut, 1972, 13, 182-188

\title{
Intestinal bacterial flora and bile salt studies in hypogammaglobulinaemia
}

\author{
D. M. PARKIN, D. B. L. McClelland, R. R. O'MOORE, I. W. PERCY-ROBB, \\ I. W. B. GRANT, AND D. J. C. SHEARMAN \\ From the Gastrointestinal Section of the University Department of Therapeutics, the University Department \\ of Clinical Chemistry, The Royal Infirmary, and the Respiratory Diseases Unit, Northern General Hospital, \\ Edinburgh
}

SUMMARY Five patients with adult acquired hypogammaglobulinaemia, four of whom were achlorhydric, were studied. Jejunal bacterial counts were much higher than those in a control group of acid secretors, but were similar to those in a control group of patients with pernicious anaemia; Giardia lamblia were isolated from the jejunal content of all patients with hypogammaglobulinaemia. The concentration of conjugated bile acids in the fasting state was lower in hypogammaglobulinaemia than in pernicious anaemia, but in the two hypogammaglobulinaemic patients with steatorrhoea there was a normal bile salt response to a fatty meal.

Gastrointestinal symptoms occur frequently in patients with hypogammaglobulinaemia, and Rosen and Janeway (1966) reported that more than half of such patients have diarrhoea or steatorrhoea. In those patients in whom a flat intestinal biopsy is accompanied by hypogammaglobulinaemia or selective IgA deficiency, a gluten-free diet may result in clinical improvement (Green and Sperber, 1962; Crabbé and Heremans, 1967). In other cases, the administration of fresh plasma which contains IgA has been associated with remission of diarrhoea (Binder and Reynolds, 1967; Gryboski, Self, Clemett, and Herskovic, 1968), and where a response to oral broad-spectrum antibiotics is found (Gryboski et al, 1968; Mawas, Sors, and Bernier, 1969; Collins and Ellis, 1965) proliferation of bacteria in the intestine may be the cause of the diarrhoea and steatorrhoea.

Previous studies have included a few observations on the flora of the upper gastrointestinal tract (Collins and Ellis, 1965; McCarthy, Austad, and Read, 1965; Mawas et al, 1969; Dubois, Roy, Fulginiti, Merrill, and Murray, 1970) but apart from one study (Hersh, Floch, Binder, Conn, Prizont, and Spiro, 1970) there has been no attempt to quantitate jejunal bacteria in a series of patients with hypogammaglobulinaemia. In the present study, an attempt is made to correlate the gastrointestinal disturbance in patients with hypogammaglobulin-

Received for publication 28 November 1971. aemia with the number of bacteria in the jejunum and with possible abnormalities of bile salt metabolism. Deconjugation of bile salts can be the cause of steatorrhoea in patients without immunological deficiency (Gorbach and Tabaqchali, 1969).

\section{Materials and Methods}

\section{PATIENTS}

The clinical details of five patients with adult acquired hypogammaglobulinaemia are shown in Table I. Three of the patients with hypogammaglobulinaemia were receiving long-term antibiotic therapy for chest infection. This was stopped for a period of three weeks before any of the studies was performed. A further five subjects who had no evidence of gastrointestinal disease were used as normal controls. Eight additional patients with pernicious anaemia were studied because four of the five patients with hypogammaglobulinaemia were achlorhydric.

\section{METHODS}

The 24-hour output of faecal fat was estimated from five-day stool collections by the method of van der Kamer, Ten Bokkel Huinink, and Weijers (1949). The normal value is $6 \mathrm{~g} / 24 \mathrm{hr}$ or less while the subject receives a dietary fat load of less than $70 \mathrm{~g} / 24 \mathrm{hr}$. Vitamin $B_{12}$ absorption was estimated by the Schilling test and by the whole-body counting method (Finlayson, Simpson, Tothill, Samson, Girdwood, 


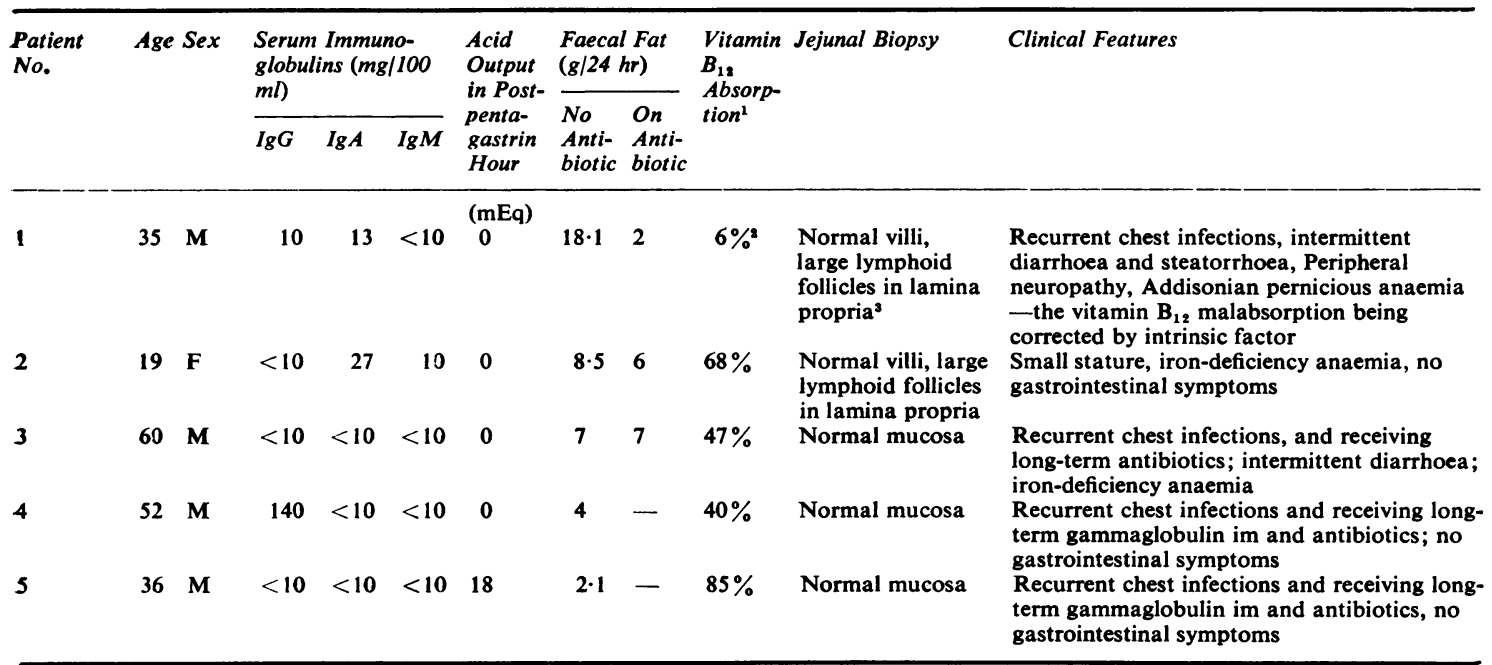

Table I Clinical details of patients with hypogammaglobulinaemia

'Whole body count

${ }^{2}$ The malabsorption in this patient was corrected by oral intrinsic factor (14\% absorption as assessed by Schilling test). Figure 3

and Shearman, 1969) in which the normal patient absorbs not less than $30 \%$ of the oral dose vitamin $B_{12}$.

Jejunal biopsy was performed with the Crosby capsule, the specimen being taken from between 2 and $10 \mathrm{~cm}$ beyond the duodeno-jejunal flexure.

\section{SERUM IMMUNOGLOBULINS}

Serum levels of immunoglobulins were measured by the Mancini technique as modified by Fahey and McKelvey (1965) using antisera supplied by Hyland Laboratories $^{1}$ and standard sera supplied by Hoechst ${ }^{2}$.

\section{INTUBATION AND SAMPLING}

All intubations were performed after an overnight fast. Intestinal secretions were aspirated via a sterile radioopaque double-lumen tube, which was passed orally. The distal end of the tube was fitted with a balloon filled with barium sulphate. The tube was guided into the upper jejunum (the first $30 \mathrm{~cm}$ of bowel beyond the duodeno-jejunal flexure) under radiological control. The distal end of the tube was unsealed, but the proximal end was firmly clamped during the intubation.

With the tube in position, aspiration of jejunal juice was performed. The first $8 \mathrm{ml}$ of aspirate was discarded. Two $3 \mathrm{ml}$ aliquots were then collected for

${ }^{1}$ Hyland Division Travend Laboratories, Thetford, Norfolk.

'Hoechst Pharmaceuticals, Hoechst House, Kew Bridge, Brentford, Middlesex. bile salt analysis and quantitative bacteriology. Samples for bile salt estimation were immediately stored at $-20^{\circ} \mathrm{C}$. The first stages of the bacteriological analysis were carried out within three minutes of collection.

The tube was then slowly withdrawn into the stomach and after five to 10 minutes in situ aspiration of gastric juice via the second lumen was performed. The first 5 to $10 \mathrm{ml}$ of aspirate was discarded, further samples being analysed for bacterial content and $p \mathrm{H}$.

\section{BACTERIOLOGICAL STUDIES}

Serial tenfold dilutions of the intestinal secretions were prepared in broth which had been rendered anaerobic by pre-steaming and storage in an oxygenfree atmosphere for 24 hours. The culture media are shown in Table II. Plates for isolation of anaerobic organisms were stored in an oxygen-free atmosphere until immediately before use.

Media 1 and 2 were inoculated by spreading the surface of the plates with $0.1 \mathrm{ml}$ of undiluted intestinal fluid and of tenfold dilutions up to $10^{-6}$. Media 3 to 10 were inoculated with single drops of each dilution according to the method of Miles and Misra (1938). The plates for anaerobic incubation were immediately sealed in BTL anaerobic jars, incubation being carried out in an atmosphere of hydrogen containing $5 \% \mathrm{CO}_{2}$. In order to limit the loss of oxygen-sensitive organisms the interval between aspiration of intestinal fluid and the completion of the above manoeuvre was less than 15 


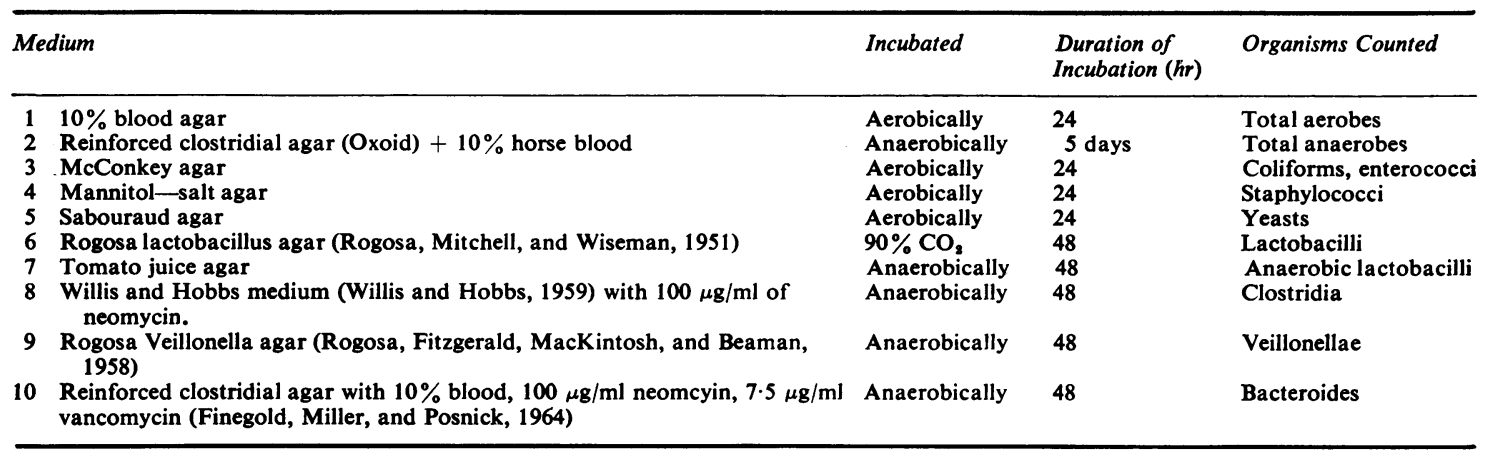

Table II Details of bacteriological analyses

minutes. Incubation was carried out at $37^{\circ} \mathrm{C}$ for the times specified in Table II.

Bacteria were identified using the tables of Cowan and Steel (1970). Plates were set up in triplicate. The colonies on each plate were counted and the mean value was used to calculate the number of organisms present in the original sample.

Samples of jejunal juice were also examined microscopically for the presence of Giardia lamblia.

\section{BILE SALT STUDIES}

Analysis of samples of jejunal juice was performed by a thin-layer chromatography technique. Samples were extracted and thin-layer chromatograms developed as described previously (Percy-Robb, Jalan, McManus, and Sircus, 1971). The developed chromatograms were heated at $100^{\circ} \mathrm{C}$ for five minutes in a hot-air oven and sprayed with acetic acid, sulphuric acid, anisaldehyde: $30,1,0.5 \mathrm{v} / \mathrm{v} / \mathrm{v}$ (Kritchevsky, Martak, and Rothblatt, 1963). The sprayed plates were returned to the hot-air oven for six and a half minutes and after $\mathbf{2 0}$ minutes at room temperature they were scanned on a flying-spot densitometer (Vitatron TLD 100). Quantitation of the individual spots was performed by analysing standard samples containing known concentrations of bile acid conjugates with glycine and taurine as well as unconjugated acids. Comparison of the areas under the peaks produced by the unknown samples was carried out with a calibration curve prepared from the standard samples. Each analysis was performed in duplicate. The concentration of total conjugated bile acids was estimated by summating the concentrations of the individual conjugates. The coefficient of variation of these quantitative analyses is between 1.5 and $5.5 \%$. The recoveries of conjugated bile acids added to jejunal juice were 96 to $103 \%$ (O'Moore and Percy-Robb, in preparation).

In patients 1 and 2 , a formal assessment of the concentration of bile salts in the upper jejunum in the 90 minutes following ingestion of a fat-containing meal (sucrose $50 \mathrm{~g}$, corn oil $20 \mathrm{~g}$, egg albumen $20 \mathrm{~g}$, water $200 \mathrm{ml}$ ) was carried out. Samples were collected immediately before ingesting the meal and thereafter at 30,60, and 90 minutes.

Organisms isolated from the jejunal juice were incubated in the presence of taurocholate ${ }^{3}(4.0 \mathrm{~m}$ moles/l) for a period of 48 hours and the appearance of unconjugated cholic acid assessed by thin-layer chromatography.

\section{Results}

The results of the faecal fat output in the patients with hypogammaglobulinaemia are shown in Tables I and IV, and in the patients with pernicious anaemia in Table IV. The findings on jejunal biopsy, and the vitamin $\mathbf{B}_{12}$ absorption of the patients with hypogammaglobulinaemia are shown in Table I.

\section{SERUM IMMUNOGLOBULIN LEVELS}

The serum immunoglobulin levels in the control patients, both normal and with pernicious anaemia, were all within the normal range for the laboratory (IgG: 700 to $1,675 \mathrm{mg} / 100 \mathrm{ml}$. IgA: 89 to $315 \mathrm{mg} /$ $100 \mathrm{ml}$. IgM: 45 to $250 \mathrm{mg} / 100 \mathrm{ml}$ ). The results in the patients with hypogammaglobulinaemia are shown in Table I.

\section{BACTERIOLOGICAL STUDIES}

The $p \mathrm{H}$ of the gastric contents of the normal control subjects was between $1 \cdot 1$ and $4 \cdot 0$. In these subjects, bacteriological analysis of jejunal juice showed only a scanty growth of organisms, mainly streptococci, lactobacilli, and veillonellae, the mean logarithmic counts being $3.6,2.4$ and 2.5 organisms per $\mathrm{ml}$, respectively.

The results of bacteriological studies in the patients with hypogammaglobulinaemia are shown in Table III, and compared with those in pernicious anaemia

'Maybridge Chemical Co., Tintagel, Cornwall. 


\begin{tabular}{|c|c|c|c|c|c|c|c|c|c|c|}
\hline Patient & $\begin{array}{l}\text { Enteric } \\
\text { Organisms } \\
\text { (Entero- } \\
\text { bacteriaceae } \\
\text { and Entero- } \\
\text { cocci) }\end{array}$ & $\begin{array}{l}\text { Strepto- } \\
\text { cocci } \\
\text { (Viridans/ } \\
\text { Salivarius) }\end{array}$ & Neisseriae & $\begin{array}{l}\text { Staphylo- } \\
\text { cocci }\end{array}$ & Yeasts & $\begin{array}{l}\text { Aerobic } \\
\text { Lacto- } \\
\text { bacilli }\end{array}$ & $\begin{array}{l}\text { Anaerobic } \\
\text { Lactobacilli } \\
\text { (Bifido- } \\
\text { bacteria) }\end{array}$ & Veillonellae & Clostridia & $\begin{array}{l}\text { Bacteroides } \\
\text { and Fusiforms }\end{array}$ \\
\hline $\begin{array}{l}1 \\
2 \\
3 \\
4 \\
5\end{array}$ & $\begin{array}{l}3 \cdot 2^{\mathrm{E}} \\
4 \cdot 6^{\mathrm{S}} \\
7 \cdot 1^{\mathrm{E}} \\
6 \cdot 9^{\mathrm{E}} \\
-\end{array}$ & $\begin{array}{l}7 \cdot 1 \\
3 \cdot 1 \\
7 \cdot 3 \\
7 \cdot 5 \\
3 \cdot 4\end{array}$ & $\begin{array}{l}6 \cdot 1 \\
4 \cdot 4 \\
7 \cdot 1 \\
6 \cdot 2 \\
3 \cdot 5\end{array}$ & $\begin{array}{l}3 \cdot 0 \\
3 \cdot 7 \\
2 \cdot 5 \\
4 \cdot 8 \\
-\end{array}$ & $\begin{array}{l}- \\
- \\
-\end{array}$ & $\begin{array}{l}3 \cdot 8 \\
3 \cdot 0 \\
2 \cdot 3 \\
- \\
-\end{array}$ & $\begin{array}{l}6 \cdot 5 \\
3 \cdot 6 \\
6 \cdot 7 \\
7 \cdot 2 \\
5 \cdot 0\end{array}$ & $\begin{array}{l}6 \cdot 3 \\
3 \cdot 5 \\
7 \cdot 8 \\
5 \cdot 7 \\
3 \cdot 6\end{array}$ & $\begin{array}{l}- \\
- \\
-\end{array}$ & $\begin{array}{l}4 \cdot 4 \\
\overline{7 \cdot 0} \\
6 \cdot 9 \\
-\end{array}$ \\
\hline
\end{tabular}

Table III Jejunal organisms

$\mathbf{E}=$ Enterobacteriaceac

$\mathbf{S}=$ Streptococci (enterococci)

Counts $=\log$ no. of organisms per $\mathrm{ml}-=<1.7$

in Figures 1 and 2. Although the patients with hypogammaglobulinaemia have relatively high bacterial counts in the jejunum when compared with normal subjects, they are unremarkable in comparison with counts obtained from the group of patients with pernicious anaemia.

When the anaerobic flora of the jejunum in the patients with hypogammaglobulinaemia and patients with pernicious anaemia are compared (Fig. 2), it is seen that three of the hypogammaglobulinaemics had bacteroides species (when these are regarded separately from the 'fusiforms'), whereas the patients with pernicious anaemia did not.

Microscopic examination of jejunal juice showed that all the patients with hypogammaglobulinaemia harboured the protozoon Giardia lamblia in the jejunum. This organism was also found in one of the control patients with pernicious anaemia, but was not present in the normal subjects.

\section{BILE SALT STUDIES}

The results of the bile salt analyses on the jejunal juice of fasting patients are shown in Table IV. Unconjugated cholic acid was found in four of the patients with hypogammaglobulinaemia and in six of the patients with pernicious anaemia. The concentration of total conjugated bile acids was between 3.2 and $15.5 \mathrm{~m}$ moles/ 1 in the patients with pernicious anaemia and 0.5 to $2.5 \mathrm{~m}$ moles $/ 1$ in the patients with hypogammaglobulinaemia.

In response to the fat-containing meal, the concentrations of bile salts in the upper jejunum of

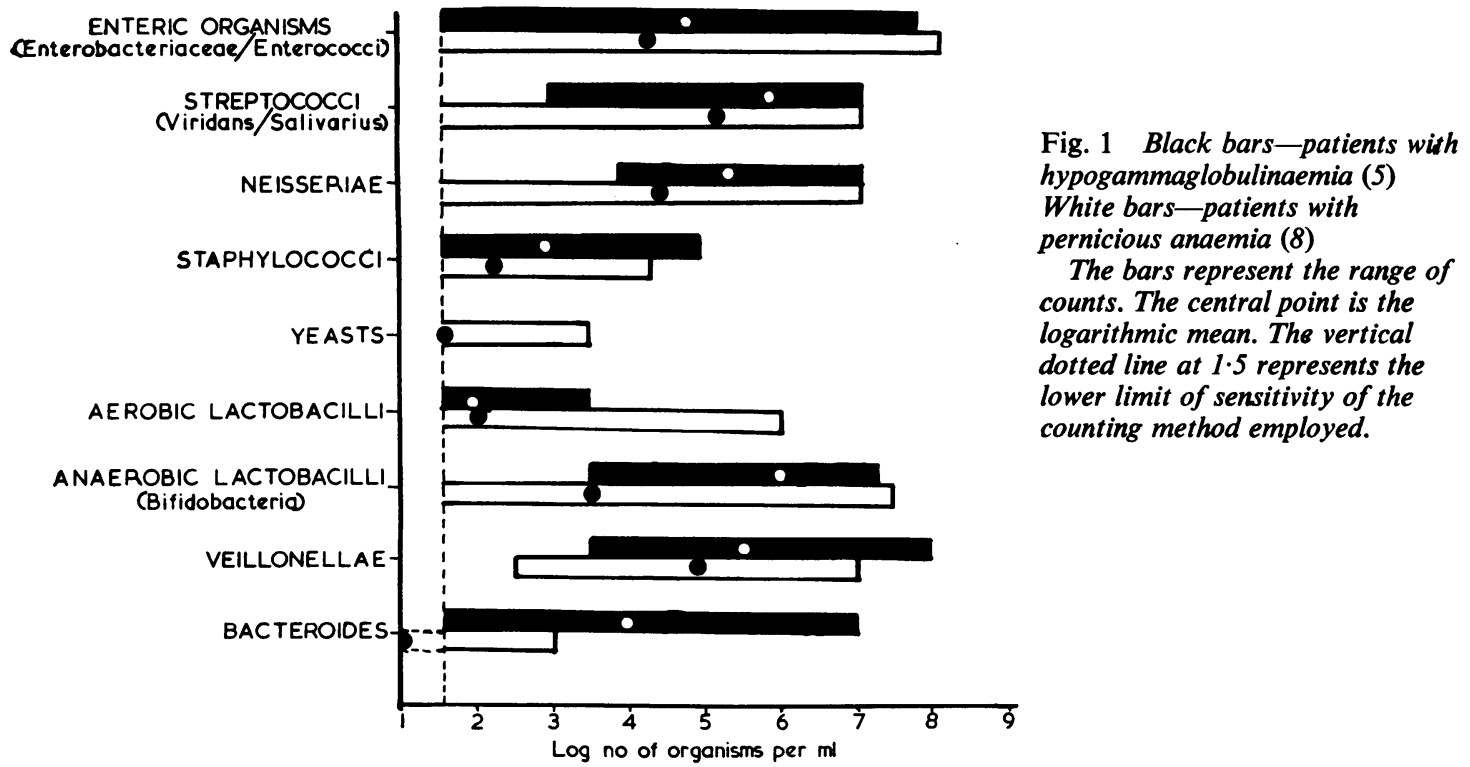




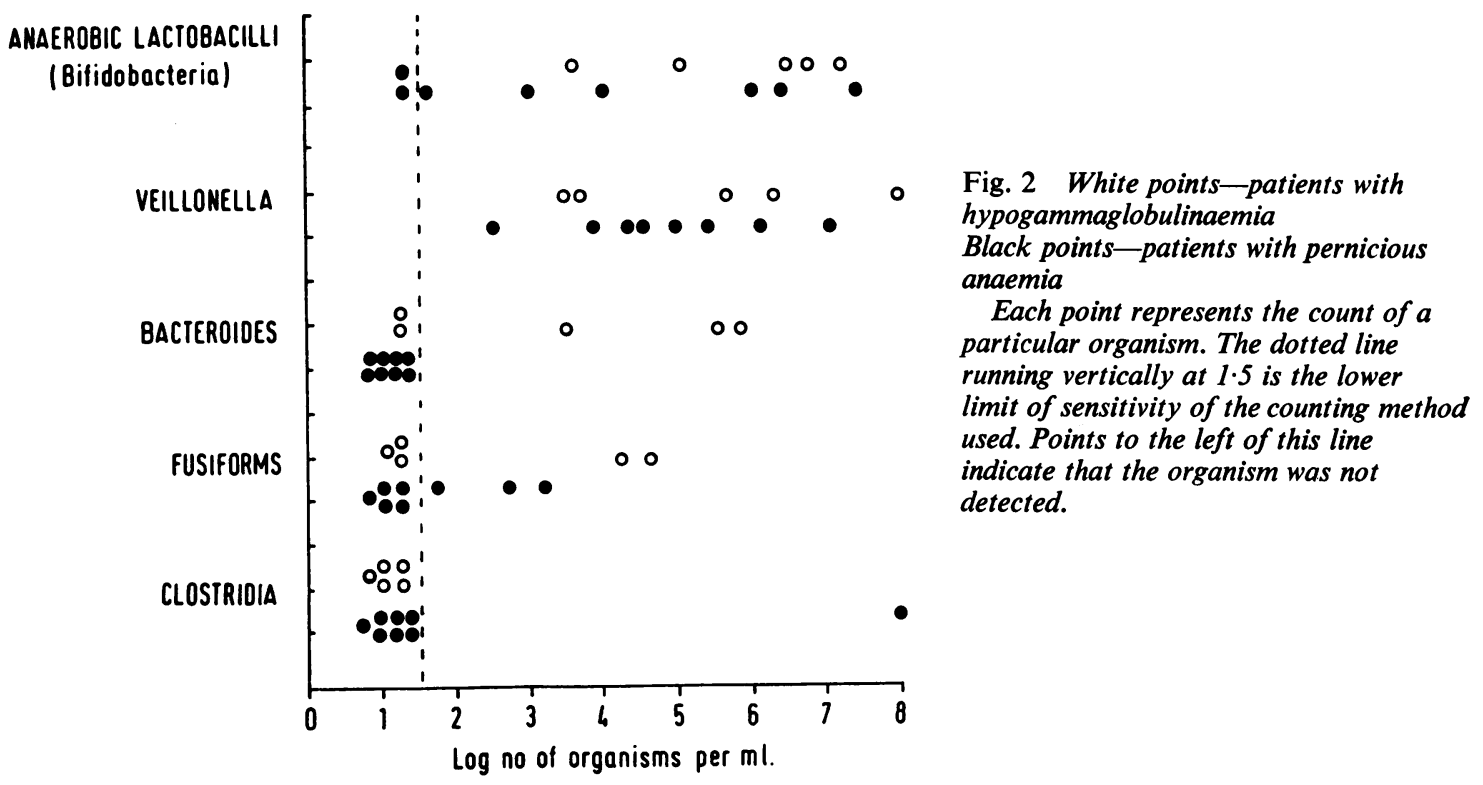

patient 1 at 30,60 , and 90 minutes were 10,7 , and $5 \mathrm{~m}$ moles/1, and in patient 2 the concentrations were 17,10 , and $13 \mathrm{~m}$ moles $/ 1$.

Organisms which were isolated from the jejunum of the patients and found to be capable of deconjugating taurocholate in vitro were Streptococcus faecalis, a strain of Bacteroides $s p$, a strain of Veillonella $s p$, and two types of anaerobic lactobacilli.

\section{Discussion}

The role of the immunoglobulins in external secretions is not fully understood. IgA is the pre- dominant immunoglobulin in the gastrointestinal tract, where it is secreted as a complex with a glycoprotein, the 'secretory piece' as $11 \mathrm{~S}$, secretory IgA. It has been suggested (Tomasi, 1969) that immunoglobulins play an important part in the regulation of the normal flora, and the resistance of mucous surfaces to colonization by potentially pathogenic microorganisms and viruses. If this is correct, then in hypogammaglobulinaemia, the intestinal conditions might exist for the proliferation of bacteria. In the patients with hypogammaglobulinaemia, the results of jejunal culture which showed large numbers of organisms compared to normal controls were similar to those described by Hersh et

\begin{tabular}{|c|c|c|c|c|c|}
\hline \multirow[t]{2}{*}{ Patient } & \multicolumn{4}{|c|}{ Concentrations of Bile Acids in Jejunum (Fasting) (mmol/l) } & \multirow{2}{*}{$\begin{array}{l}\text { Faecal Fat Output } \\
(g / 24 \mathrm{hr})\end{array}$} \\
\hline & Total Conjugated & Cholic & Chenodeoxycholic & Deoxycholic & \\
\hline 1 & $2 \cdot 5$ & $0 \cdot 17$ & $0 \cdot 10$ & $\mathbf{0}$ & $18 \cdot 1$ \\
\hline 2 & 1.5 & 0.04 & 0 & $\mathbf{0}$ & 8.5 \\
\hline 3 & 1.5 & 0.08 & $\mathbf{0}$ & 0 & 7 \\
\hline 4 & 1.5 & 0.06 & $\mathbf{0}$ & 0 & 4 \\
\hline 5 & 0.5 & 0 & $\mathbf{0}$ & $\mathbf{0}$ & $2 \cdot 1$ \\
\hline 6 & $15 \cdot 5$ & $\mathbf{0}$ & $\mathbf{0}$ & $\mathbf{0}$ & $7 \cdot 0$ \\
\hline 7 & $3 \cdot 2$ & 0 & $\mathbf{0}$ & $\mathbf{0}$ & $3 \cdot 2$ \\
\hline 8 & $5 \cdot 3$ & $0 \cdot 10$ & $\mathbf{0}$ & $\mathbf{0}$ & 4.7 \\
\hline 9 & 5.4 & $0 \cdot 16$ & 0.06 & 0 & 4.9 \\
\hline 10 & $10 \cdot 6$ & $0 \cdot 20$ & 0.05 & 0 & 7.9 \\
\hline 11 & 4.0 & $0 \cdot 12$ & 0.07 & 0.04 & $3 \cdot 6$ \\
\hline 12 & $5 \cdot 6$ & $0 \cdot 22$ & $0 \cdot 10$ & 0.05 & 5.5 \\
\hline 13 & $6 \cdot 5$ & 0.55 & 0.15 & 0.08 & $5 \cdot 3$ \\
\hline
\end{tabular}

Table IV Bile salt concentrations in jejunal juice from patients with hypogammaglobulinaemia (patients 1 to 5$)$ and pernicious anaemia (patients 6 to 13) 


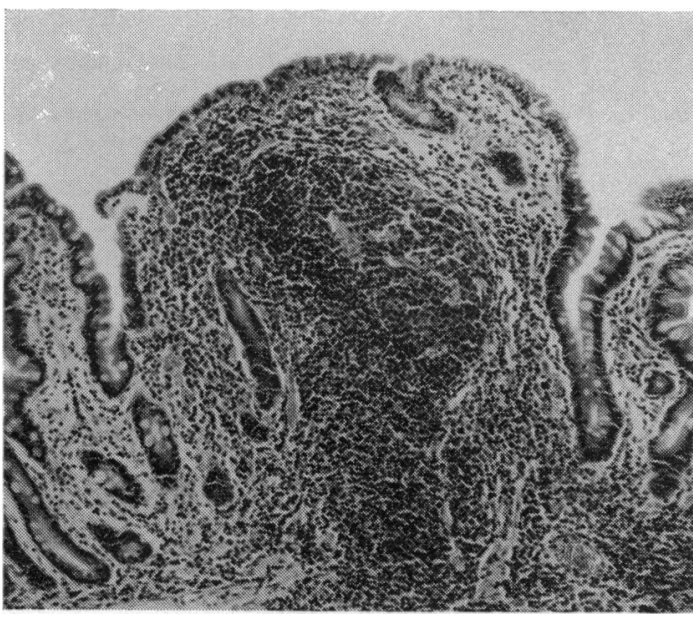

Fig. 3 Jejunal biopsy from patient no. 1, showing nodular lymphoid hyperplasia.

al (1970) except that we found relatively large numbers of Bacteroides in three out of five patients. Gastric achlorhydria is a common finding in patients with immunoglobulin deficiency diseases (Twomey, Jordan, Laughter, Meuwissen, and Good, 1970), and the absence of gastric acid is associated with increased numbers of bacteria in the jejunum (Sherwood, Goldstein, Haurani, and Wirts, 1964). For this reason, it is essential that the gastric acidity of all patients studied should be known before counts of organisms obtained from the upper small bowel can be considered abnormal. In the study by Hersh et al (1970) only one of the patients with significant numbers of organisms in the upper jejunum was shown to have 'normal' gastric acidity. Because four of our patients were achlorhydric, we have compared them with patients with pernicious anaemia. The differences between the two groups were unremarkable, apart from the presence of Bacteroides in three of the patients with hypogammaglobulinaemia (Fig. 2). In spite of the presence of bacterial colonization in the upper small intestine, none of the patients with pernicious anaemia had gastrointestinal symptoms. Two of the five patients with hypogammaglobulinaemia had gastrointestinal symptoms but we did not demonstrate any correlation between the jejunal flora and the clinical and laboratory features of the bowel disorder. It was noted that Giardia lamblia was present in the jejunal aspirate of all patients with hypogammaglobulinaemia compared with only one of the patients with pernicious anaemia. Others have found the diarrhoea to be relieved in the occasional patient by eradicating the Giardia but in the present study this treatment could not be carried out separately because of the limited time that three of the five patients could remain untreated with antibiotics.

The presence of an abnormal flora in the upper small intestine can be associated with malabsorption of fat due to the production of unconjugated bile acids (being the products of bacterial deconjugation of bile acid conjugates). This causes a reduction in the concentration of these conjugates to a level below that necessary for the production of micelles, and fat malabsorption results. The concentration of total conjugated bile acids in the jejunum of fasting patients was lower in the hypogammaglobulinaemic group than in the eight patients with pernicious anaemia.

However, it was demonstrated that in response to a fatty meal, patients 1 and 2 (faecal fat excretion 18.1 and $8.5 \mathrm{~g}$ respectively) achieved adequate concentrations (Badley, Murphy, and Bouchier, 1969) of conjugated bile acid for normal fat absorption to occur. It seems unlikely that these low fasting bile acid concentrations in the hypogammaglobulinaemic group were due to malabsorption of bile salts since it has been demonstrated that a subnormal response to a fatty meal accompanies bile salt malabsorption, eg, in ileal resection (Van Deest et al, 1968; Percy-Robb et al, 1970). Decreased bile salt synthesis is unlikely in view of the normal bile salt response to a fat load. A dilutional effec. has not been excluded in this study. Thus, although the fasting revels of conjugates in hypogammaglobulinaemia and pernicious anaemia appeared different, there was no evidence that the low level in hypogammaglobulinaemia reflected differences in bile salt concentration in response to food.

In the present study, some of the patients with hypogammaglobulinaemia and some of those with pernicious anaemia had low concentrations of unconjugated bile acids in the jejunal aspirate, and studies in vitro defined some of the bacteria which were capable of deconjugation. Both the morphology (Dawson and Isselbacher, 1960; Low-Beer, Schneider, and Dobbins, 1970) and function (Dawson and Isselbacher, 1960; Dietschy, 1967) of the small intestine of the rat, guinea pig, and hamster may be altered by the presence of unconjugated bile acids in the intestinal lumen. However, the concentrations of unconjugated acids required to produce these effects have been shown to be, in general, greater than $1 \mathrm{mM}$ although a concentration of $5 \times 10^{-4} \mathrm{M}$ of deoxycholate has been shown to inhibit fatty acid esterification (Dawson and Isselbacher, 1960). It is unlikely that the presence of unconjugated bile acids which we have found in our patients is related to the 
mechanism of malabsorption since there was no relation between their concentration and the presence of a raised faecal fat excretion.

Whilst it is appreciated that the present study did not proceed to assess the bacteriological flora at different levels in the small intestine (Gorbach and Tabaqchali, 1969) and did not assess whether the bile salt response to a fatty meal could be sustained on subsequent occasions (van Deest, Fordtran, Morawski, and Wilson, 1968; Percy-Robb et al, 1971) we could demonstrate no specific factors causing gastrointestinal disturbance and steatorrhoea. It may be that disturbance is due to a combination of minor mucosal abnormalities and repeated viral and bacterial infections, together with the presence of Giardia lamblia.

Dr D. M. Parkin and Dr D. B. L. McClelland were in receipt of MRC junior research fellowships. We thank our technical staff Mr R. R. Samson and Mr K. Marwick, for their assistance.

\section{References}

Badley, B. W. D., Murphy, G. M., and Bouchier, I. A. D. (1969) Intraluminal bile salt deficiency in the pathogenesis of steatorrhoea. Lancet, 2, 400-402.

Binder, H. J., and Reynolds, R. D. (1967). Control of diarrhea in secondary hypogammaglobulinemia by fresh plasma infusions. New Engl. J. Med., 277, 802-803.

Collins, J. R., and Ellis, D. S. (1965). Agammaglobulinemia, malabsorption and rheumatoid-like arthritis. Amer. J. Med., 39, 476-482.

Cowan, S. T., and Steel, K. J. (1970). Manual for the Identification of Medical Bacteria. Cambridge University Press, London.

Crabbé, P. A., and Heremans, J. F. (1967). Selective IgA deficiency with steatorrhea. Amer. J. Med., 42, 319-326.

Dawson, A. M., and Isselbacher, K. J. (1960). Studies on lipid metabolism in the small intestine with observations on the role of bile salts. J. clin. Invest., 39, 730-740.

Dietschy, J. M. (1967). Effects of bile salts on intermediate metabolism of the intestinal mucosa. Fed. Proc., 26, 1589-1598.

Dubois, R. S., Roy, C. C., Fulginiti, V. A., Merrill, D. A., and Murray, R. L. (1970). Disaccharidase deficiency in children with immunologic deficits. J. Pediat., 76, 377-385.

Fahey, J. L., and McKelvey, E. M. (1965). Quantitative determination of serum immunoglobulins in antibody-agar plates. J. Immunol., 94, 84-90.

Finegold, S. M., Miller, A. B., and Posnick, D. J. (1964). Further studies on selective media for bacteroides and other anaerobes. Ernährungsforschung, 10, 517-528.

Finlayson, N. D. C., Simpson, J. D., Tothill, P., Samson, R. R., Girdwood, R. H., and Shearman, D. J. C. (1969). Application of whole-body counting to the measurement of vitamin $B_{18}$ absorption with reference to achlorhydria. Scand.J. Gastroent., 4, 397-405.

Gorbach, S. L., and Tabaqchali, S. (1969). Bacteria, bile and the small bowel. Gut, 10, 963-972.

Green, I., and Sperber, R. J. (1962). Hypogammaglobulinemia, arthritis, sprue, and megaloblastic anemia. N.Y. St. J. Med., 62, 1679-1686.

Gryboski, J. D., Self, T. W., Clemett, A., and Herskovic, T. (1968). Selective immunoglobulin A deficiency and intestinal nodular lymphoid hyperplasia: correction of diarrhea with antibiotics and plasma. Pediatrics, 42, 833-837.

Hermans, P. E., Huizenga, K. A., Hoffman, H. N., II, Brown, A. L., Jr., and Markowitz, H. (1966). Dysgammaglobulinemia associated with nodular lymphoid hyperplasia of the small intestine. Amer. J. Med., 40, 78-89.

Hersh, T., Floch, M. H., Binder, H. J., Conn, H. O., Prizont, R., and Spiro, H. M. (1970). Disturbance of the jejunal and colonic bacterial flora in immunoglobulin deficiencies. Amer. J. clin. Nutr., 23, 1595-1601.

Van de Kamer, J. H., ten Bokkel Huinink, H., and Weyers, H. A. (1949). Rapid method for the determination of fat in feces. J. biol. Chem., 177, 347-355.

Kritchevsky, D., Martak, D. S., and Rothblat, G. H. (1963). Detection of bile acids in thin-layer chromatography. Analyt. Biochem., $5,388-392$.

Low-Beer, T. S., Schneider, R. E., and Dobbins, W. O. (1970). Morphological changes of the small-intestinal mucosa of guinea pig and hamster following incubation in vitro and perfusion in vivo with unconjugated bile salts. Gut, 11, 486-492.

McCarthy, C. F., Austad, W. I., and Read, A. E. A. (1965). Hypogammaglobulinemia and steatorrhea. Amer. J. dig. Dis., 10, 945-957.

Mawas, C., Sors, C., and Bernier, J. J. (1969). Amyloidosis associated with primary agammaglobulinemia, severe diarrhea and familial hypogammaglobulinemia. Amer. J. Med. 46, 624-634.

Miles, A. A., and Misra, S. S. (1938). The estimation of the bactericidal power of the blood. J. Hyg. (Lond.), 38, 732-749.

Percy-Robb, I. W., Jalan, K. N., McManus, J. P. A., and Sircus, W. S. (1971). Bile salt metabolism in ileostomy patients with and without ileal resection. Clin. Sci., in press.

Rogosa, M., Fitzgerald, R. J., MacKintosh, M. E., and Beaman, A. J. (1958). Improved medium for selective isolation of veillonella. J. Bact., 76, 455-456.

Rogosa, M., Mitchell, J. A., and Wiseman, R. F. (1951). A selective medium for the isolation and enumeration of oral and fecal lactobacilli. J. Bact., 62, 132-133.

Rosen, F. S., and Janeway, C. A. (1966). The gamma globulins. III. The antibody deficiency syndromes. New Engl. J. Med., 275, 709-715.

Sherwood, W. C., Goldstein, F., Haurani, F. I., and Wirts, C. W. (1964). Studies of the small-intestinal bacterial flora and of intestinal absorption in pernicious anemia. Amer. J. dig. Dis., 9, 416-425.

Tomasi, T. B., Jr, (1969). On the mechanisms of transport and biological significance of antibodies in external secretions. Arthr. and Rheum., 12, 45-50.

Twomey, J. J., Jordan, P. H., Jr., Laughter, A. H., Meuwissen, H. J., and Good, R. A. (1970). The gastric disorder in immunoglobulin-deficient patients. Ann. intern. Med., 72, 499-504.

Van Deest, B. W., Fordtran, J. S., Morawski, S. G., and Wilson, J. D. (1968). Bile salt and micellar fat concentration in proximal small bowel contents of ileectomy patients. J. clin. Invest., 47, 1314-1324.

Willis, A. T., and Hobbs, G. (1959). Some new media for the isolation and identification of clostridia. J. Path. Bact., 77, 511-521. 